\title{
MINI TINJAUAN \\ PENGEMBANGAN SDM SISTEM INFORMASI GEOGRAFIS
}

\author{
Nurul Amelia (0305203006)
}

\author{
Program Studi Pendidikan Matematika \\ Fakultas Ilmu Tarbiyah dan Keguruan UIN Sumatera Utara \\ Jl. William Iskandar Pasar V, Medan Estate \\ Email : nurulaamelia18@gmail.com
}

\begin{abstract}
Abstrak
Sistem Informasi Geografis dalam bahasa Inggris merupakan Geographic Information System ataupun kerap disingkat (GIS) ini merupakan sesuatu sistem data yang berbasis pc serta dirancang buat bisa bekerja dengan memakai informasi yang memiliki data spasial ataupun rujukan keruangan. Sistem informasi geografis (SIG) ini merupakan suatu sistem yang sanggup buat membangun serta memanipulasi dan menunjukkan data yang memiliki rujukan geografis. Sistem ini mengintrogasi mengecek menganalisa serta memanipulasi semacam yang disebutkan di atas tadi dan pula menunjukkan informasi keadaan bumi. Sistem informasi geografis juga merupakan sebuah sistem berbasis pc yang kerap digunakan buat bisa memasukkan menaruh mengelola serta pula mengaktifkan kembali informasi yang mempunyai rujukan keruangan buat seluruh berbagai tujuan yang berkaitan ataupun berhubungan dengan pemetaan dan perencanaan. Secara universal penafsiran SIG merupakan sesuatu komponen yang terdiri dari perangkat keras, perangkat lunak, informasi geografis serta sumber energi manusia yang bekerja bersama secara efisien buat memasukan, menaruh, membetulkan, memperbaharui, mengelola, memanipulasi, mengintegrasikan, menganalisa dan menunjukkan informasi dalam sesuatu data berbasis geografis.
\end{abstract}

Kata Kunci : SDM, GIS, Komponen, Informasi.

\section{A. PENDAHULUAN}

Pada umumnya sebutan Sistem Informasi Geografis (SIG) ini adalah gabungan dari tiga faktor pokok yakni sistem, data, serta geografis. Dengan memandang unsur-unsur tersebut, sehingga jelas sistem informasi geografis (SIG) merupakan sesuatu sistem informasi yang menekankan pada aspek "informasi geografis" sistem data geografis pula terdiri dari data spasial dan aspasial.

Konsep umum atau konsep dasar sistem informasi geografis yang dirancang serta terbuat buat bekerja dengan informasi si yang referensi secara spasial ataupun koordinatkoordinat geografi dan juga mempunyai keahlian untuk melaksanakan pengolahan informasi serta melaksanakan operasi-operasi tertentu dengan menunjukkan serta menggali informasi

Perkembangan aplikasi sistem informasi geografis di kala ini tidak hanya secara jumlah aplikasi namun pula bertambah berasal dari jenis keragaman aplikasinya. Pengembangan aplikasi proses data geografis kedepannya mengarah ke terhadap aplikasi berbasis website yang dikenal bersama sistem informasi geografis. 
Prinsip utama aplikasi ini adalah mengubah data menjadi informasi dan rekomendasi yang nantinya mudah untuk dipahami oleh masyarakat umum. Dan juga diharapkan bisa pula diakses oleh seluruh masyarakat dengan gampang lewat Single Window.

Selaku salah satu tipe sistem data yang berbasis PC sistem informasi geografis tentunya memerlukan perangkat PC sebagai komponen-komponen utama atau komponen dasar yang juga termasuk sumber daya manusia yang mengoperasikannya perihal ini ini tidak lain dan tidak bukan semacam prinsip dasar pengoperasian PC.

Biasanya kalau proses yang hendak terjalin tentu diawali dengan ketersediaan brainware, hardware, serta aplikasi. Maka dari itu sebagian penulis berkomentar kalau sistem informasi geografis merupakan perlengkapan atau tata cara serta prosedur yang hendak memudahkan serta memesankan penyajian data dan tidak hanya 3 komponen inti tersebut. Dalam sistem informasi geografis dibutuhkan juga prosedur kerja informasi si serta sistem data.

Sistem Informasi ini adalah suatu sistem yang berbasis isi untuk pengolahan, penyimpanan, pemrosesan, analisis, dan penayangan ataupun display data yang terpaut dengan permukaan bumi.

SIG akhir- akhir ini hadapi pertumbuhan yang pesat bersamaan dengan kemajuan dalam bidang teknologi informasi. Di Indonesia, bergulirnya otonomi wilayah sebagian tahun yang kemudian dan kenaikan kebutuhan hendak data kebumian dalam rangka pengelolaan sumber energi alam jadi salah satu aspek kenaikan pemakaian SIG.

SIG sudah banyak digunakan dalam kehidupan sehari- hari di bermacam bidang, apalagi untuk sebagian besar kalangan, SIG telah menjelma jadi suatu kebutuhan yang tidak dapat ditinggalkan.

\section{B. STUDI LITERATUR}

Studi literatur yang digunakan yaitu dengan menekuni serta menguasai teori yang dipergunakan dengan mencari faktor- faktor yang jadi ketentuan sistem data geografi. Seperti contohnya teori metode penginderaan jarak jauh data - data tersebut dicari dengan metode mengumpulkan literatur. Sistem pengolahan informas tumbuh sangat gila bersamaan dengan pesatnya pertumbuhan teknologi PC salah satu sistem pengolahan data yang sangat terkenal di sebagian Negara maju spesialnya dalam bidang survei dan pemetaan ialah sistem informasi geografis.

\section{METODE}

\section{Judul Artikel}

Judul artikel pada karya ini adalah "Perkembangan Sistem Informasi Geografis (SIG)."

\section{Metode}

Metode yang digunakan dalam membuat artikel ini yaitu dalam bentuk studi dokumentasi atau studi pustaka dengan menganalisa Sumber Daya Alam SIG dengan 
menggunakan buku dan juga digital book/jurnal online sebagai referensi dalam menyusun artikel.

\section{PEMBAHASAN}

Pada dasarnya SIG mampu ditunaikan secara manual namun didalam ulasan selanjutnya SIG selalu diasosiasikan dengan sistem knowledge yang berbasis pc sangat menolong kala informasi geografis yang ada ialah informasi jumlah serta dimensi besar serta terdiri dari banyak tema yang silih berkaitan.

SIG pula memiliki keahlian buat menghubungkan bermacam informasi pada sesuatu titik spesifik di bumi, menggabungkannya, menganalisa serta kesimpulannya memetakan hasilnya. Informasi yang diolah pada SIG ialah Info spasial, Ini merupakan suatu Info yang berorientasi geografis serta ialah posisi yang mempunyai sistem koordinat spesifik selaku basic referensinya.

Oleh sebabnya, terdapatlah aplikasi SIG yang bisa menanggapi sebagian persoalan semacam posisi, keadaan, transportasi serta permodelan. Keahlian inilah yang membedakan SIG dari sistem data yang lain.

Konsep dasar SIG sistem yang dirancang buat bekerja dengan data yang tereferensi secara spasial maupun koordinat- koordinat geografi. SIG memiliki kemampuan buat melakukan pengolahan data serta melakukan operasi - operasi tertentu dengan menunjukkan serta menganalisa informasi.

Bisa digunakan pula buat mengkaji kerentanan sesuatu daerah terhadap ancaman musibah tertentu dengan akurasi serta ketepatan yang bisa dipertanggung jawabkan sang bisa menolong mengelola informasi jadi data yang menyajikan dalam wujud Softcopy serta Hardcopy sehingga lebih fleksibel penggunaannya oleh para stakeholder yang berkaitan dengan musibah.

Selaku contoh bisa menolong perencanaan kedaruratan buat memudahkan perhitungan reaksi kedaruratan pada dikala terbentuknya musibah alam, ataupun SIG bisa dipakai buat menciptakan tanah basah ladang perkebunan yang dibutuhkan buat melindungi dari bahaya polusi serta pula musibah alam tercantum kekeringan, gempa bumi, tanah longsor, kehancuran area, musibah akibat kegiatan penambangan, serta angin puting beliung, yang menimbulkan akibat yang rusak pada bermacam kegiatan ataupun kepemilikan.

Untuk itu memakai perlengkapan serta bahan yang hendak dipakai buat riset.

a. Alat

Perlengkapan yang dipakai dalam riset ini meliputi perangkat keras, berbentuk laptop serta perangkat lunak berbentuk aplikasi QGis 2.8 dan aplikasi pendukung lainnya.

b. Bahan

Terdapat bahan - bahan serta informasi yang hendak dipakai buat melaksanakan riset terhadap sesuatu akibat musibah.

Aplikasi SIG dikala kini berkembang tidak cuma secara jumlah aplikasi tetapi pula meningkat dari tipe keragaman aplikasinya. Pengembangan aplikasi SIG kedepannya menuju kepada aplikasi berbasis Website yang diketahui bersama SIG. 
Pertumbuhan aplikasi sistem data geografis di kala ini tidak cuma secara jumlah aplikasi tetapi pula bertambah berasal dari Jenis keragaman aplikasinya. Pengembangan aplikasi sistem informasi geografis kedepannya mengarah ke terhadap aplikasi berbasis web site yang dikenal bersama sistem informasi geografis. Contohnya semacam sistem Website Monitoring berbasis aplikasi website yang berisikan data serta saran geologi, hidrologi, geografi serta yang lain ataupun diucap water tingkat, curah hujan, temperatur maupun yang lain. Yang disajikan secara informatif dalam tampilan map ataupun peta serta pula sistem ini dibentuk serta dibesarkan secara mandiri memakai PHP Codeigniter $3 \mathrm{xx}$.

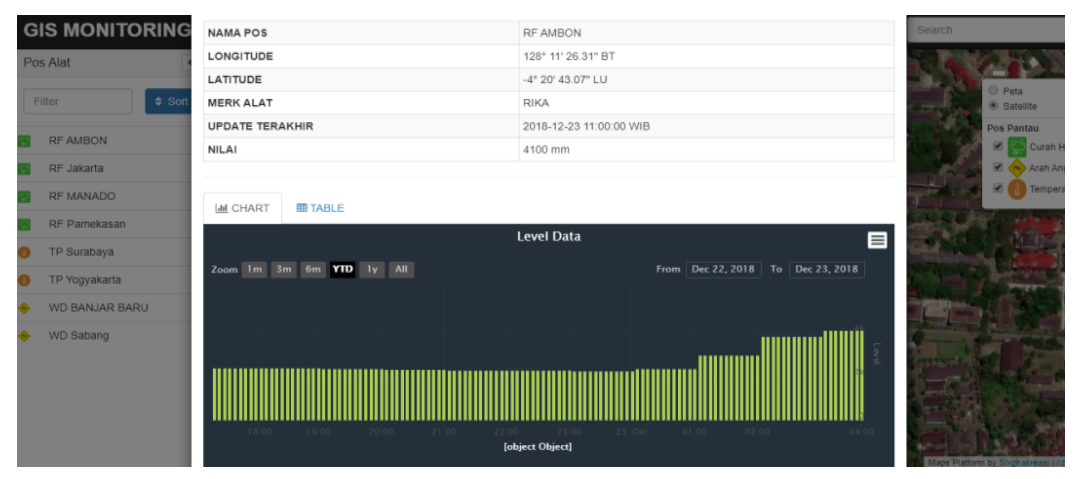

Gambar 1. Contoh Web Monitoring

Selaku salah satu tipe sistem data yang berbasis pc, SIG nyatanya memerlukan seperangkat pc selaku komponen- komponen utamanya tercantum sumberdaya manusia yang mengoperasikannya. Menimpa ini tidak lain semacam prinsip dasar pengoperasian pc pada umumnya, bila proses yang hendak terjalin tentu diawali dengan ketersediaan brainware, hardware serta aplikasi.

SIG dibangun dengan komponen- komponen yang silih berhubungan. Komponen yang digunakan dalam pengembangan SIG merupakan Perangkat Keras (Hardware), Perangkat Lunak (Software), Manusia (Brainware/User). itu berfungsi berarti buat pertumbuhan SIG. Saya hendak menarangkan satu persatu tentang ketiganya.

1. Perangkat Keras (Hardware)

Bagian- bagian perangkat keras yang menunjang pertumbuhan SIG beserta gunanya ialah:

a. CPU

CPU (Central Processing Unit) merupakan sirkuit elektronik di dalam pc yang melaksanakan instruksi yang membentuk program pc. CPU melaksanakan pembedahan aritmatika, logika, pengendalian, serta input/ output dasar yang didetetapkan oleh instruksi dalam program.

b. VDU

VDU (Visual Display Unit) berbentuk sinyal elektronik, dalam perihal ini berbentuk foto yang tampak di layar monitor. Foto yang tampak merupakan hasil pemrosesan informasi maupun data masukan. Buat menunjukkan proses serta hasil analisis SIG di fitur pc. Keberadaan VDU jadi sangat berarti sebab berkaitan dengan subsistem SIG pada bagian Keluaran ataupun Output. 


\section{c. Disk drive}

Suatu komponen perangkat keras yang menyimpan informasi sekunder serta berisi piringan magnetis.

Termasuk anggota CPU untuk memunculkan suatu program. .

d. Tape drive

Perangkat penyimpanan informasi yang membaca serta menulis informasi pada pita magnetik.

Salah satu anggota dari CPU yang menyimpan knowledge hasil pemrosesan.

e. Digitizer

Mesin mengganti objek analog, foto, ataupun sinyal jadi format digital. Digunakan selaku perlengkapan buat mengganti informasi teristris jadi informasi digital( digitasi).

f. Printer

Perlengkapan buat mencetak informasi ataupun peta dalam dimensi relatif kecil.

g. Plotter

Printer grafis yang menggambar dengan memakai pena- pena tinta, selaku fitur output awal yang sanggup mencetak foto berdimensi foto sebesar arsitektur serta engineering.

Berperan semacam printer, digunakan buat mencetak peta namun keluarannya lebih lebar.

2. Perangkat lunak (Software)

yakni komponen SIG yang berwujud program- program pendukung kerja SIG semacam input data, proses data, dan output data. Contoh fitur lunak dari SIG ialah program kerja semacam Q- GIS, ArchView, dan ArcGis.

3. Manusia (Brainware/User)

Yakni pelaksana yang bertanggung jawab di dalam pengumpulan, proses, analisis, serta publikasi geografis. Komponen brainware- lah yang memproduksi information hasil lapangan buat setelah itu diproses ataupun digitasi jadi suatu peta yang mampu digunakan buat kepentingan khusus cocok bersama dengan gunanya.

yakni pelaksana yang bertanggung jawab di dalam pengumpulan, proses, analisis, dan publikasi information geografis. Komponen brainware-lah yang memproduksi information hasil lapangan untuk sesudah itu diproses atau digitasi menjadi sebuah peta yang sanggup digunakan untuk kepentingan spesifik sesuai bersama dengan fungsinya.

Sudah dipaparkan termasuk di awal bahwa SIG merupakan sesuatu kesatuan sistem yang terdiri dari bermacam komponen tidak cuma fitur perangkat keras computer beserta bersama dengan perangkat lunaknya namun mesti ada information geografis yang akurat serta sumber tenaga manusia buat melakukan kedudukannya di dalam memformulasikan serta menganalisa permasalahan buat seleksi keberhasilan SIG. 


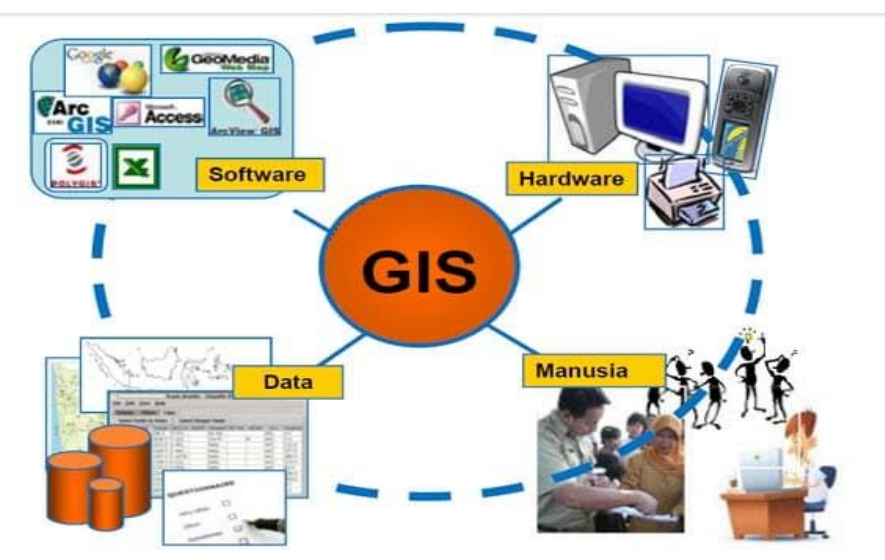

\section{Gambar 2. Komponen SIG}

Fungsi Sistem Data Geografis adalah sebagai berikut:

a. Input Data

Saat sebelum informasi tersebut wajib dikonversi terlebih dulu ke dalam wujud digital. Proses konversi informasi dari peta kertas ataupun gambar ke dalam wujud digital. Proses konversi informasi kertas ataupun gambar ke dalam wujud digital diucap dengan digitzing. SIG modern dapat melaksanakan proses ini secara otomatis memakai teknologi scanning.

b. Pembuatan Peta

Dalam proses pembuatan peta memakai sistem data geografis lebih fleksibel dibanding dengan metode manual ataupun semacam kartografi otomatis. Prosesnya pula dimulai dengan pembuatan database peta kertas bisa di digital kan serta data digital tersebut bisa pula dimaksud kedalam sistem data geografi peta yang hendak dihasilkan bisa terbuat dengan memakai skala serta bisa menampilkan data yang diseleksi cocok dengan ciri tertentu.

Sistem Data Geografis( SIG) merupakan sistem data yang berdasar pada informasi keruangan serta merepresentasikan obyek di bumi. Dalam SIG sendiri teknologi data ialah perangkat yang menolong dalam menaruh datas, memproses informasi, menganalisa informasi, mengelola informasi serta menyajikan data.

c. Manipulasi Data

Informasi dalam sistem data geografis hendak memerlukan transformasi ataupun motivasi buat membuat informasi tersebut wajib kompatibel dengan sistem teknologi ini pula sediakan bermacam berbagai perlengkapan bantu buat memanipulasi informasi yang terdapat serta menghapus informasi yang tidak digunakan.

d. Manajemen File

Manajemen file digunakan kala volume informasi yang terdapat terus menjadi besar serta hasil informasi user terus menjadi banyak hingga perihal baik yang wajib dicoba ialah memakai database management system (DBMS) untuk membantu menyimpan, mengendalikan serta mengelola ulang informasi. 


\section{e. Analisis Query}

Sistem data geografis pula menyediakan kapasitas buat menunjukkan query serta kebutuhan buat menganalisis data yang ada. Teknologi Sistem Informasi Geografis digunakan buat menganalisa informasi geografis serta pula buat memandang pola serta trend.

f. Memvisualisasikan hasil

Visualisasi hasil buat bermacam berbagai jenis pembedahan geografis hasil kesimpulannya divisualisasikan dalam wujud peta. Peta ini sangat efektif buat menaruh serta mendialogkan data geografis. Tetapi dikala ini pula mengintegrasikan tampilan peta dengan memperoleh laporan serta pula menunjukkan 3 ukuran serta multimedia.

Informasi dalam SIG terdiri atas 2 komponen ialah data spasial yang berhubungan dengan geometri wujud keruangan serta informasi attribute yang membagikan data tentang wujud keruangannya.

Data spasial merupakan informasi yang bereferensi geografis atas representasi obyek di bumi. data spasial merupakan informasi yang mempunyai rujukan ruang kebumian di mana bermacam informasi atribut terletak dalam bermacam unit spasial informasi grafis yang berkaitan dengan posisi, posisi serta zona pada koordinat tertentu.

Sebagian besar information yang bisa ditangani di dalam Sig ialah information spasial information yang berorientasi geografis information ini miliki proses koordinat spesial selaku basic referensinya nya serta bawa 2 anggota berarti yang berbeda dari information lain ialah kabar daerah (spasial) serta Kabar deskriptif (atribut) yang dipaparkan berikut ini:

1. Data Daerah (spasial)

sesuatu koordinat baik koordinat geografi (lintang serta bujur) ataupun koordinat Cartesian XYZ (absis, ordinat serta ketinggian), terhitung antara lain kabar data umum serta proses proyeksi.

2. Data Deskriptif (atribut)

Data atribut ataupun Kabar non spasial, sesuatu daerah yang miliki sebagian kabar yang terpaut dengannya, contohnya: type vegetasi, populasi, luasan, kode pos, serta sebagainya. Data atribut kerapkali digunakan pula buat menampilkan mutu dari posisi.

Data Spasial mempunyai 2 tipe jenis ialah format vektor serta raster. Model informasi vektor menampilkan, menempatkan, dan menyimpan informasi spasial dengan mengenakan titik- titik, garis- garis maupun kurva, maupun poligon beserta atribut- atributnya.

a. Data Vektor

Suatu yang berupa suatu titik, ataupun garis yang menghubungkan titik- titik tersebut. Keuntungan utama dari format informasi vektor merupakan ketepatan didalam merepresentasikan fitur titik, batas serta garis lurus. Perihal ini sangat berfaedah buat analisa yang memerlukan ketepatan posisi, apabila pada basis informasi batas- batas kadaster. 


\section{b. Data Raster}

Informasi yang dihasilkan dari sistem Penginderaan Jauh. Pada informasi raster, obyek geografis dipresentasikan sebagai lapisan sel grid yang diucap dengan pixel (picture element).

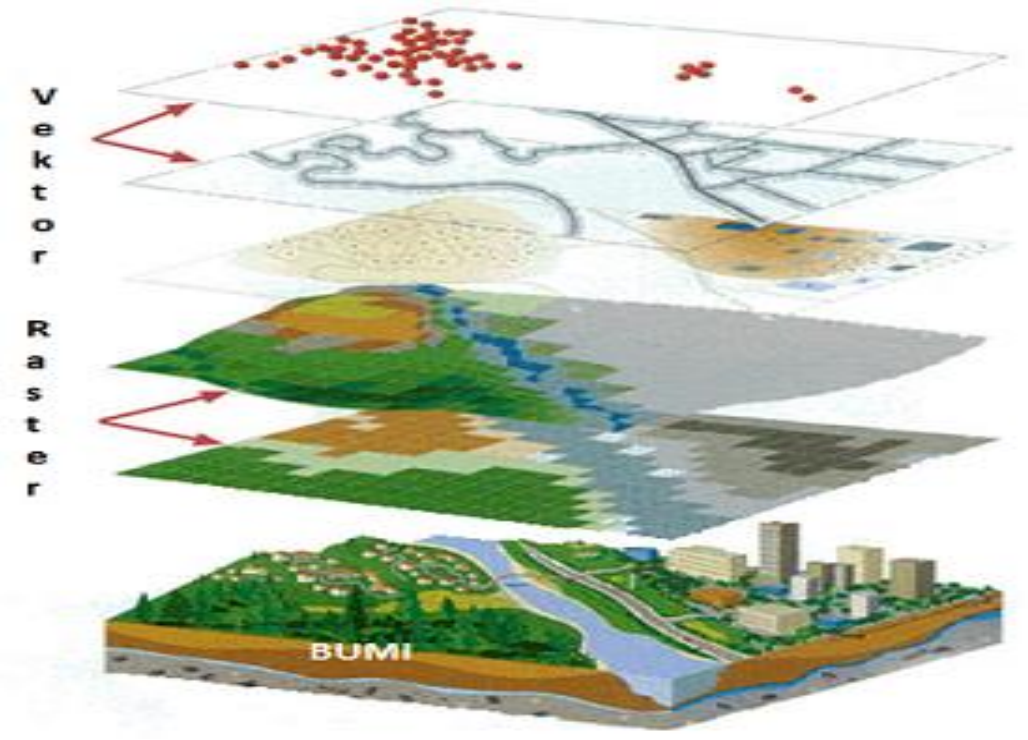

Gambar 3. Vektor \& Raster Pada Bumi

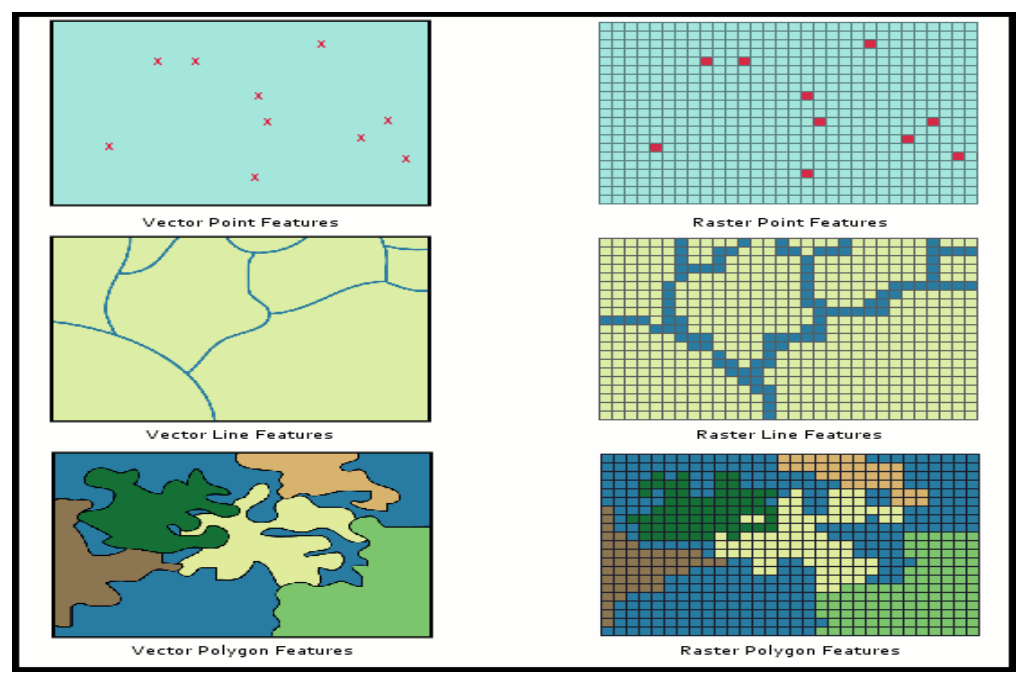

Gambar 4. Data Vektor \& Raster Features

Dalam mempraktikkan data Spasial diperlukan Metode. Salah satunya Metode pendekatan, ini bisa dijalankan selaku satu diantara tata cara kajian yang ada di SIG. Informasi yang dibutuhkan bermula dari informasi spasial yang memiliki kodifikasi informasi yang bertabiat integritas. Contohnya bisa berbentuk peta yang memiliki pangkat data akurat ialah peta pemakaian lahan. 
1. Metode Integritas

Tata cara pendekatan ini dapat diterapkan sebagai salah satu tata metode analisis yang terdapat di SIG. Data yang diperlukan berasal dari data spasial yang mempunyai klasifikasi data yang bersifat kualitatif. Contohnya dapat berupa peta yang mempunyai tingkatan data kualitatif yakni peta konsumsi lahan.

2. Tata cara Kuantitatif

- Metode Kuantitatif Binary

Pendekatan ini Menggunakan operasi logika AND yang ada di di dalam alogaritma. Sehingga di dalam pengharkatan terhadap parameter kelas yang digunakan, hanya 2 kelas yakni nilai 1( diterima) serta pula nilai 0( tidak diterima). Masing- masing parameter yang digunakan, terlebih sempat wajib dinilai apakah di terima maupun tidak di terima suatu kelas parameter.

- Metode Kuantitatif Berjenjang

Pendekatan kuantitatif ini memberikan nilai yang mirip membuat masing- masing komponen di dalam menganalisis. Masing- masing komponen yang digunakan mempunyai harkat yang mirip membuat dianalisis, dengan beranggap jikalau masing- masing komponen memiliki pengaruh yang mirip terhadap objek yang dianalisis.

Metode Kuantitatif Berjenjang Tertimbang, Pendekatan ini selamanya memberikan nilai pengharkatan, namun Menggunakan bobot yang berlainan membuat masing - masing variabel yang digunakan di dalam menganalisis. Pemberian bobot bergantung terhadap besar maupun kecilnya pengaruh variabel berikut yang ada terhadap tema analisis.

Metode ini pula membagikan anggapan, bila tiap variabel memiliki pengaruh yang berbeda bergantung dari tujuan objek yang dianalisis.

Data Atribut beri tambahan gambaran atau mengatakan Info mengenai bersama fitur peta atau konversi knowledge atribut dapat disimpan sebagai format angka ataupun sifat tetapi terhadap proses Info geografis utamanya diarsir dan ARC/INFO knowledge atribut dihubungkan bersama knowledge spasial melalui identifier atau kerap disingkat ID yang mengenai di fitur selanjutnya terhadap art atau info knowledge atribut disimpan sebagai file info atau disebut fitur atribut table. Menurut ARC/INFO file knowledge atribut dikonservasi selaku file INFO disebut "feature attribute tables". Menurut ArcView file ketahui bersama nama "shape" file (*.SHP) yang berasal dari serangkaian file. Atribu disimpan terhadap file bersama nama ekstensi (perluasan) *.dbf.

\section{E. KESIMPULAN}

Sistem Informasi Geografis pada bahasa Inggris merupakan Geographic Information System ataupun kerap disingkat (GIS) ini suatu sistem data yang beralas pc serta dirancang buat bisa bekerja dengan memakai informasi yang memiliki data spasial ataupun rujukan keruangan.

Selaku salah satu tipe sistem data yang berbasis PC sistem informasi geografis tentunya memerlukan perangkat PC sebagai komponen-komponen utama atau komponen 
dasar yang juga termasuk sumber daya manusia yang mengoperasikannya perihal ini ini tidak lain dan tidak bukan semacam prinsip dasar pengoperasian PC.

Biasanya kalau proses yang hendak terjalin tentu diawali dengan ketersediaan brainware, hardware, serta aplikasi. Maka dari itu sebagian penulis berkomentar kalau sistem informasi geografis merupakan perlengkapan atau tata cara serta prosedur yang hendak memudahkan serta memesankan penyajian data dan tidak hanya 3 komponen inti tersebut. Dalam sistem informasi geografis dibutuhkan juga prosedur kerja informasi si serta sistem data.

SIG akhir- akhir ini hadapi pertumbuhan yang pesat bersamaan dengan kemajuan dalam bidang teknologi informasi. Di Indonesia, bergulirnya otonomi wilayah sebagian tahun yang kemudian dan kenaikan kebutuhan hendak data kebumian dalam rangka pengelolaan sumber energi alam jadi salah satu aspek kenaikan pemakaian SIG.

Bisa digunakan pula buat mengkaji kerentanan sesuatu daerah terhadap ancaman musibah tertentu dengan akurasi serta ketepatan yang bisa dipertanggung jawabkan sang bisa menolong mengelola informasi jadi data yang menyajikan dalam wujud Softcopy serta Hardcopy.

Sistem Informasi Geografis ialah sesuatu teknologi yang sangat bermanfaat dalam menunjang pengambilan sesuatu keputusan dalam suatu bidang. Perihal ini disebabkan sistem data geografis sanggup buat mengumpulkan data serta informasi dan menganalisisnya secara spasial yang setelah itu menampilkannya dalam wujud grafik ataupun peta yang lebih efisien serta lebih gampang buat dimengerti oleh si pengguna.

Dalam teknik penyusunan peta memakai sistem informasi geografis lebih fleksibel dibanding oleh metode instruktur ataupun semacam integritas implusif. Prosesnya pula dimulai melalui penyusunan database lukisan bisa di digital kan serta data digital tersebut bisa pula dimaksud kedalam sistem data geografi peta yang hendak dihasilkan bisa terbuat dengan memakai skala serta bisa menampilkan data yang diseleksi cocok dengan ciri tertentu.

Sistem Data Geografis( SIG) merupakan skema data yang berlandaskan pada informasi keruangan serta mengutarakan tujuan di bumi. Pada SIG sendiri teknologi data ialah perangkat yang menolong dalam menaruh datas, memproses informasi, menganalisa informasi, mengelola informasi serta menyajikan data.

SIG ini merupakan sebuah sistem berbasis komputer yang digunakan atau dipakai untuk dapat memasukan, menyimpan, mengelola, menganalisis serta juga mengaktifkan kembali data yang memiliki referensi keruangan untuk segala macam tujuan yang berkaitan atau berhubungan dengan pemetaan serta perencanaan.

Sistem Informasi Geografis sebagai salah satu sistem yang berbasis komputer dan memiliki kemampuan dalam menangani data bereferensi.

Contohnya seperti sistem Web Monitoring berbasis aplikasi web yang berisikan informasi dan rekomendasi geologi, hidrologi, geografi dan lainnya atau disebut water level, curah hujan, suhu ataupun lainnya. Yang disajikan secara informatif dalam tampilan map atau peta dan juga sistem ini dibangun dan dikembangkan secara mandiri menggunakan PHP Codeigniter 3xx. 


\section{DAFTAR PUSTAKA}

Widana, I Dewa Ketut Kerta dkk. (2019). Sistem Informasi Geografis. Bogor: Makmur Cahaya Ilmu.

Aronoff, Stan. (1989). Geographic Information System: A Management Perspective. Ottawa: WDL Publications.

Barkey, Roland A dkk. (2009). Buku Ajar Sistem Informasi Geografis. Makassar: FKUH.

Sutanto. (1992). Penginderaan Jauh Jilid I dan II. Yogyakarta: Gadjah Mada Press.

https://ilmugeografi.com/geografi-dasar/analisis-spasial

https://www.dosenpendidikan.co.id/sistem-informasi-geografis/

Gambar 1. https://www.pelajaran.co.id/pengertian-sig-manfaat-komponen-dan-ruanglingkup-sistem-informasi-geografis/

Gambar 2. https://www.wawanhn.com/2018/01/mengenal-data-spasial.html

Gambar 3. https://www.wawanhn.com/2018/01/mengenal-data-spasial.html

Gambar 4. https://sixghakreasi.com/lampiran/gis/2.\%20gis\%20monitoring.PNG 